TAPROBANICA, ISSN 1800-427X. April, 2011. Vol. 03, No. 01: pp. 42-43, 2 pls.

(C) Taprobanica Private Limited, Jl. Kuricang 18 Gd.9 No.47, Ciputat 15412, Tangerang, Indonesia.

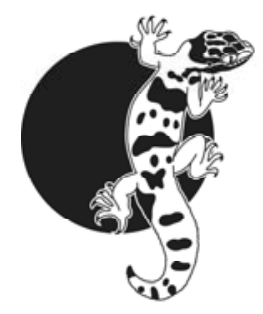

\section{Additions to black mildews of India}

Kerala is located in the south-west corner of peninsular India and towards the western side of the southern Western Ghats, harbouring rich vegetation. It is a treasure of biological wealth and it needs the specialized personalities to identify and name them. Senior author is being engaged in the study of this never completing treasure of microfungal wealth of Kerala state since three decades. This paper gives an account of four taxa, hitherto unrecorded from India, belonging to the genera Asterina and Meliola, namely, Asterina garciniicola, Meliola abrupta, Meliola bakeri and Meliola hugoniae are described and illustrated.

\section{Taxonomy}

1. Asterina garciniicola Ouyang \& Song, 1995 in Ouyang, Song \& Hu, Acta Mycologiaca Sinica, 14: 244. (Pl. 5, Fig. 1)

Colonies epiphyllous, dense, velvety, up to $5 \mathrm{~mm}$ in diameter, rarely confluent. Hyphae straight to substraight, branching opposite at acute to wide angles, loosely to closely reticulate, cells 14-29 x 7-10 $\mu \mathrm{m}$. Appressoria alternate to 2\% opposite, subopposite, unicellular, globose to cylindrical, straight to curved, antrorse to spreading, entire, 914 x 7-10 $\mu \mathrm{m}$. Thyriothecia scattered, orbicular, often connate, up to $270 \mu \mathrm{m}$ in diameter, stellately dehisced at the centre, margin crenate to fimbriate, fringed hyphae flexuous; asci globose to ovate, octosporous, up to $65 \mu \mathrm{m}$ in diameter; ascospores conglobate, uniseptate, constricted at the septum, 31-36 x 14-17 $\mu \mathrm{m}$.

Material examined: On leaves of Garcinia sp. (Clusiaceae); Loc. Pandipathal, Peppara Wildlife Sanctuary; Coll. Jacob Thomas et al.; Date. 29-II2008; Cat. no. HCIO 48847, TBGT 3223.

Asterina garciniae Hansford and A. garciniicola Ouyang \& Song are known on the host genus (Hansford, 1946; Ouyang et al., 1995). The latter species was reported on G. multiflora from China and is reported for the first time from India.

2. Meliola abrupta Sydow \& Sydow, 1917. Annales Mycologici, 15 (3-4): 181; Hansford, 1961. Sydowia Beih, 2: 292. (Pl. 5, Fig. 2)

Meliola derridis Yates, 1918. Philippine Journal of Science, 13: 368.

Colonies amphigenous, mostly epiphyllous, dense, velvety, up to $2 \mathrm{~mm}$ in diameter, confluent and covering entire upper surface of the leaves. Hyphae straight to substraight, branching mostly opposite at acute to wide angles, loosely to closely reticulate, cells 14-38 x 4-7 $\mu \mathrm{m}$. Appressoria alternate, about 5\% opposite, antrorse, curved, $12-17 \mu \mathrm{m}$ long; stalk cells cylindrical to cuneate, 2-5 $\mu \mathrm{m}$ long; head cells globose to subglobose, straight to curved, entire, 9$14 \times$ 7-12 $\mu \mathrm{m}$. Phialides mixed with appressoria, alternate to opposite, ampulliform, 16-29 x 6-12 $\mu \mathrm{m}$. Mycelial setae numerous, scattered, straight, simple, acute to dentate at the tip, up to $520 \mu \mathrm{m}$ long. Perithecia scattered, verrucose, globose, up to $160 \mu \mathrm{m}$ in diameter; ascospores cylindrical to ellipsoidal, 4-septate, constricted, 36-43 x 12-17 $\mu \mathrm{m}$.

Materials examined: On leaves of Derris sp. (Fabaceae); Loc. near Peppara dam, Peppara Wildlife Sanctuary; Coll. Jacob Thomas; Date. 18XI-2007; Cat. no. HCIO 49034, TBGT 3289.

This species reported for the first time from India (Hosagoudar, 1996 \& 2008).

3. Meliola bakeri Sydow, 1916. Annales Mycologici, 14: 335; Hansford, 1961. Sydowia Beih, 2: 374. (Pl. 6, Fig. 3)

Colonies epiphyllous, scattered, up to $2 \mathrm{~mm}$ in diameter. Hyphae straight to undulate, branching opposite at acute angles, closely reticulate, cells 1724 x 4-7 $\mu \mathrm{m}$. Appressoria alternate to opposite, antrorse to subantrorse, retrorse to spreading, 17-20 $\mu \mathrm{m}$ long; stalk cells cuneate, 4-7 $\mu \mathrm{m}$ long; head cells ovate, globose, entire, 13-16 x 8-11 $\mu \mathrm{m}$. 
Phialides mixed with appressoria, alternate to opposite, ampulliform, 19-24 x 4-7 $\mu \mathrm{m}$. Mycelial setae straight, simple, acute to obtuse at the tip, up to $580 \mu \mathrm{m}$ long. Perithecia scattered, verrucose, up to $128 \mu \mathrm{m}$ in diameter; ascospores obovoidal, 4septate, constricted, 30-38 x 13-16 $\mu \mathrm{m}$.

Materials examined: On leaves of Cayrtia pedata (Lam.) A. L. Juss ex Gagnepain (Vitaceae); Loc. Thiruvalla, Pathanamthitta, Kerala; Coll. Jacob Thomas; Date. 19-XI-2006; Cat. no. HCIO 48261, TBGT 3000.

This species reported for the first time from India (Hosagoudar, 1996 \& 2008).

4. Meliola hugoniae Hanford \& Deighton, 1948. Mycological Papers. 23: 5; Hansford, 1961. Sydowia Beih, 2: 91. (Pl. 6, Fig. 4)

Colonies epiphyllous, subdense to dense, velvety, up to $2 \mathrm{~mm}$ in diameter. Hyphae straight to substraight, branching mostly opposite at acute to wide angles, loosely to closely reticulate, cells 15$29 \times 4-7 \mu \mathrm{m}$. Appressoria opposite, about $2 \%$ alternate to unilateral, straight to curved, antrorse to spreading, $13-20 \mu \mathrm{m}$ long; stalk cells cylindrical to cuneate, 2-5 $\mu \mathrm{m}$ long; head cells ovate to oblong, entire, broadly rounded at the apex, $11-15$ x 6-9 $\mu \mathrm{m}$. Phialides mixed with appressoria, alternate to opposite, ampulliform, 17-26 x 5-7 $\mu$. Mycelial setae scattered to grouped around perithecia, simple, straight, acute to obtuse at the tip, up to $1200 \mu \mathrm{m}$ long. Perithecia scattered, up to $160 \mu \mathrm{m}$ in diameter; ascospores obovoidal, 4-septate, constricted at the septa, 28-41 x 11-17 $\mu \mathrm{m}$.

Materials examined: On leaves of Hugonia belli Sedgwick (Linaceae); Loc. Aaralam Wildlife Sanctuary, Kannur, Kerala; Coll. Jacob Thomas et al.; Date. 28-II-2007; Cat. no. HCIO 49036, TBGT 3291.

This species reported for the first time from India (Hosagoudar, 1996 \& 2008).

\section{Acknowledgements}

We thank Director, (TBGRI) for providing facilities. We are grateful to Ministry of Environment and Forest, New Delhi for the financial support and to Forest Department of Kerala for the forest permission.

\section{Literature cited}

Hansford, C. G., 1946. Contribution towards the fungus flora of Uganda - VVIII. New Records. Proceedings of the Linnean Society of London, 151: 138-212.

Hansford, C. G., 1961. The Meliolineae. A Monograph. Sydowia Beih, 2: 1-806.

Hosagoudar, V. B., 1996. Meliolales of India. Botanical Survey of India, Calcutta: 363.

Hosagoudar, V. B., 2008. Meliolales of India. Vol. II. Botanical Survey of India, Calcutta: 390.

Ouyang, Y., B. Song, and Y. Hu, 1995. Studies on the taxonomy of Asterina in China-I. Acta Mycologiaca Sinica, 14: 241-247.

Submitted: 16 May 2011, Accepted: 24 June 2011 Sectional Editor: R. K. Verma

V. B. Hosagoudar ${ }^{1,2}$, Jacob Thomas ${ }^{1}$ and D. K. Agarwal $^{3}$

\footnotetext{
${ }^{1}$ Tropical Botanic Garden and Research Institute, Palode - 695 562, Thiruvananthapuram, Kerala, India 2 vbhosagoudar@rediffmail.com

${ }^{3}$ Indian Agricultural Research Institute, Plant Pathology Division, New Delhi, India
} 


\section{PLATE 05}

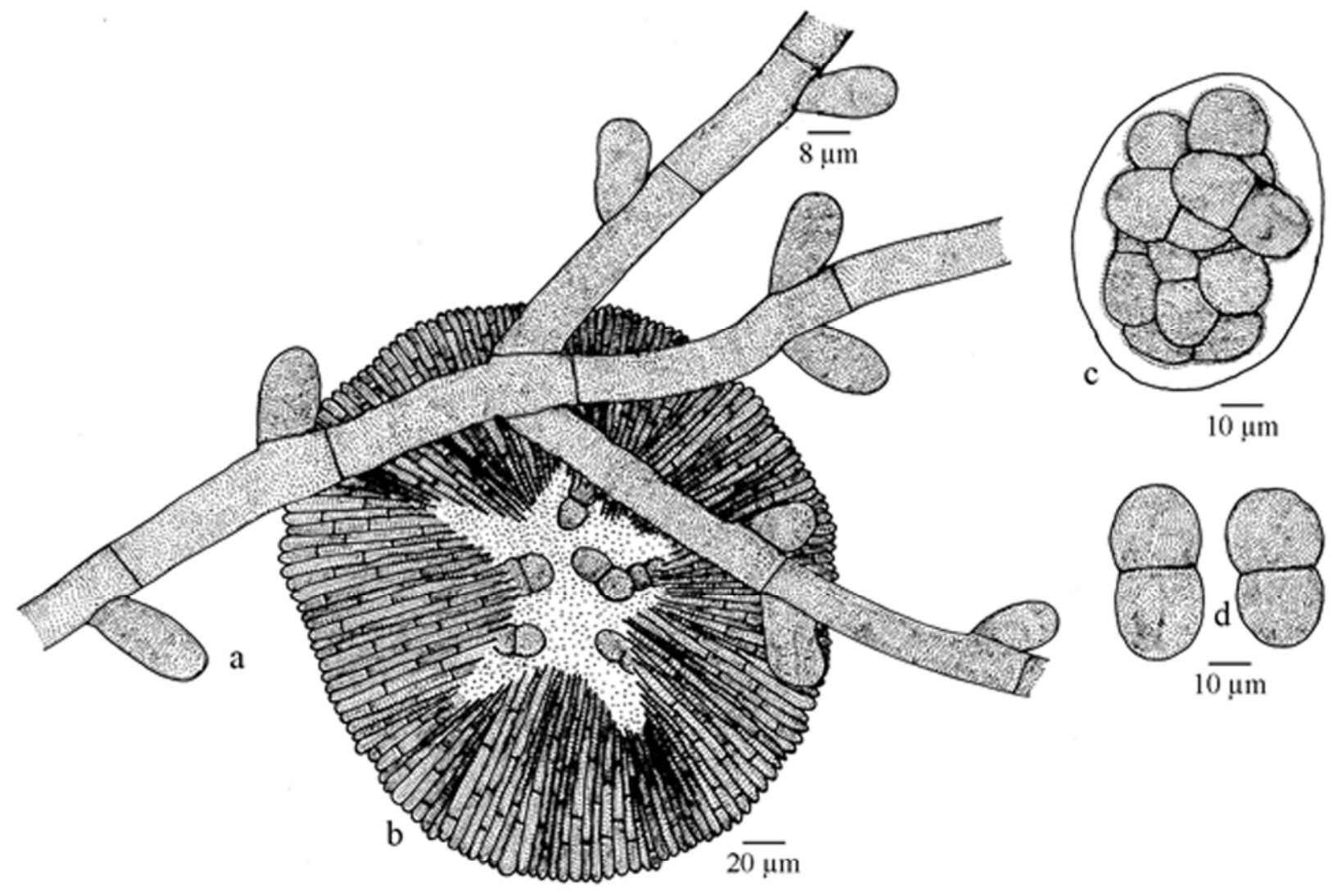

Fig. 01: Asterina garciniicola Ouyang \& Song, 1995

a. Appressoriate mycelium, b. Thyriothecium, c. Ascus, d. Ascospores

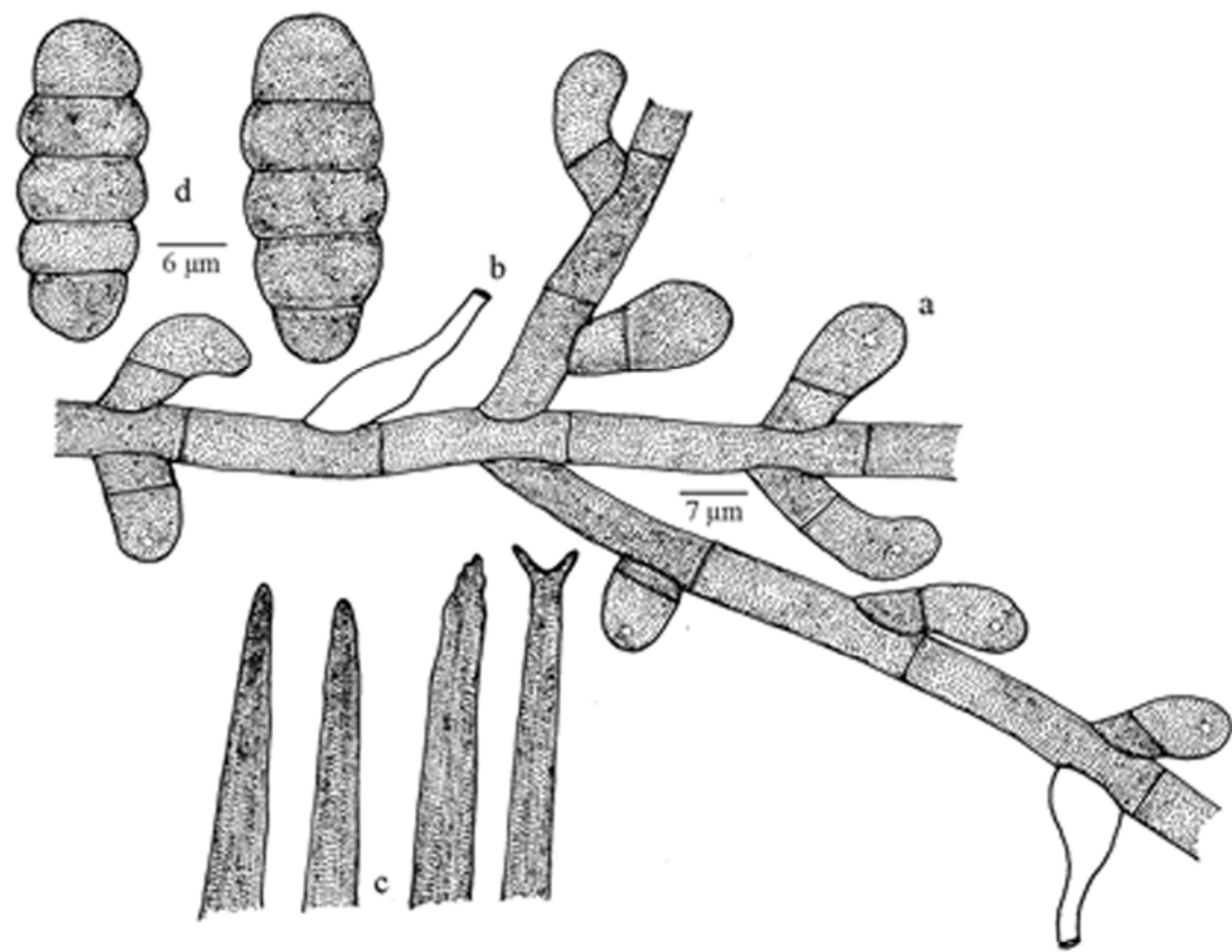

Fig. 02: Meliola abrupta Syd. \& Syd., 1917.

a. Appressorium, b. Phialide, c. Apical portion of the mycelia setae, d. Ascospores 


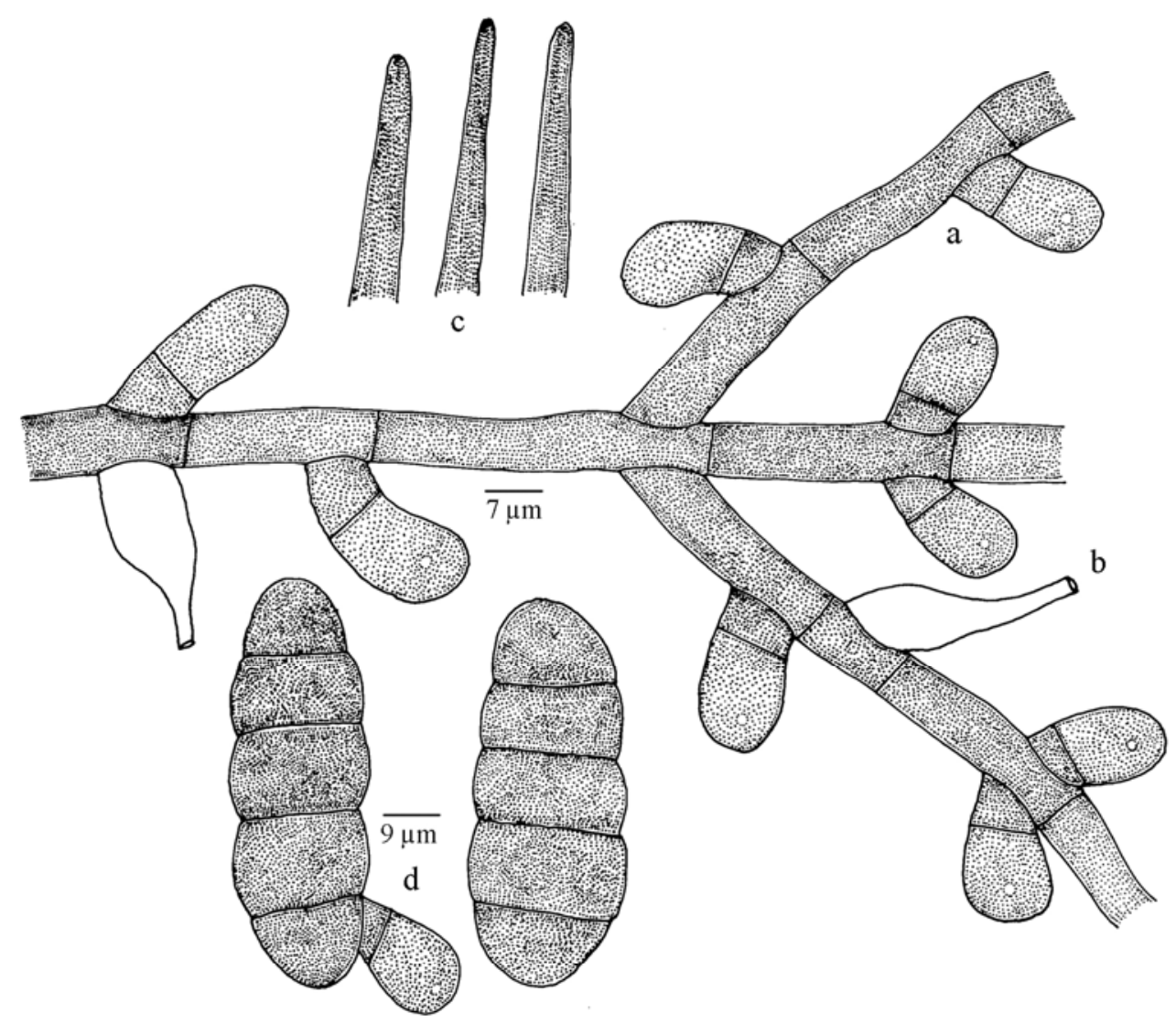

Fig. 03: Meliola bakeri Syd., 1916

a. Appressorium, b. Phialide, c. Apical portion of the mycelia setae, d. Ascospores

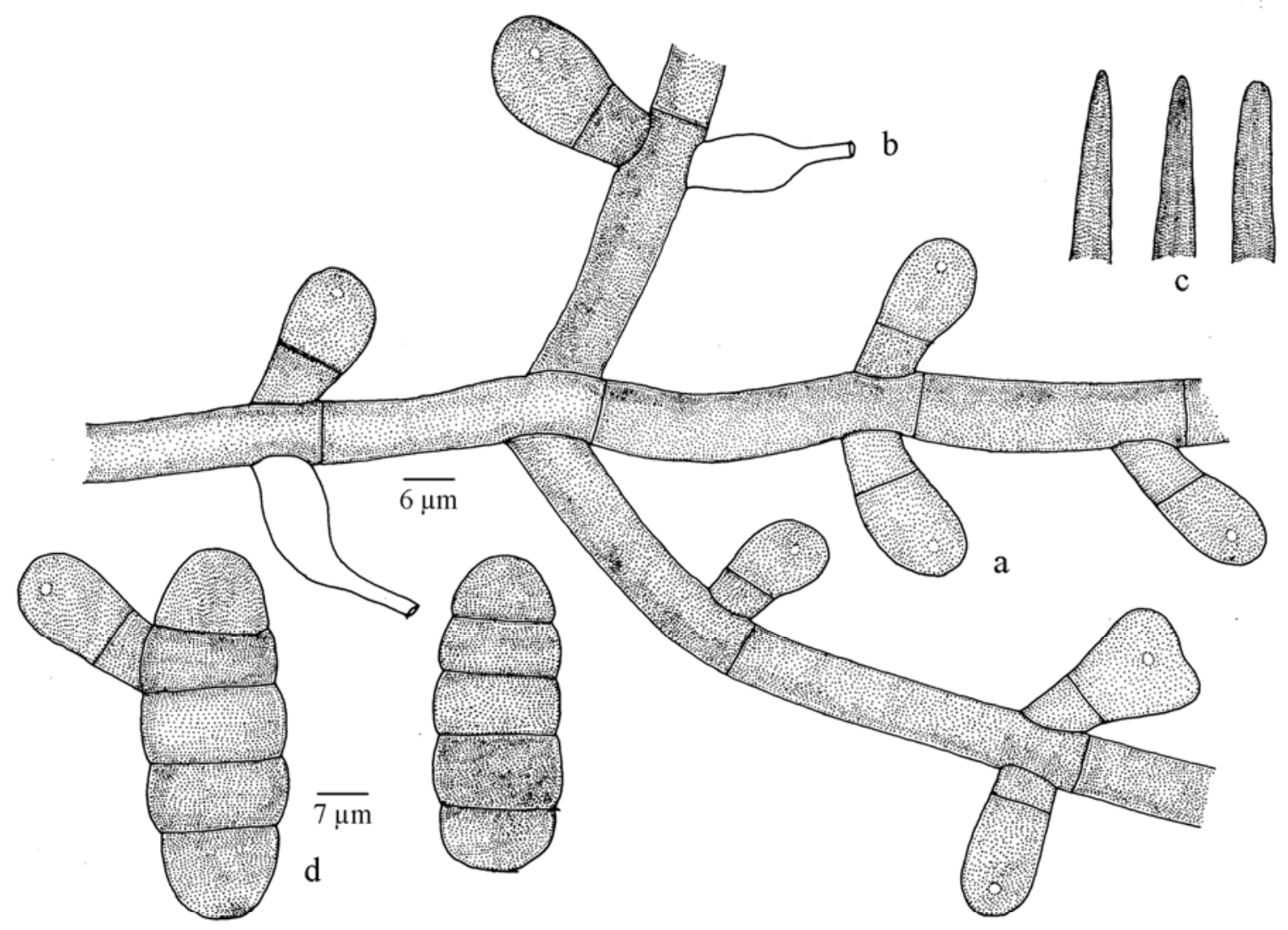

Fig. 04: Meliola hugoniae Hanf. \& Deight., 1948

a. Appressorium, b. Phialide, c. Apical portion of the mycelia setae, d. Ascospores 